\title{
KRAS Mutant Status, p16 and $\beta$-catenin Expression May Predict Local Recurrence in Patients Who Underwent Transanal Endoscopic Microsurgery (TEMS) for Stage I Rectal Cancer
}

\author{
MICHAIL SIDERIS, JANE MOORHEAD, SALVADOR DIAZ-CANO, \\ INGVAR BJARNASON, AMYN HAJI and SAVVAS PAPAGRIGORIADIS
}

Department of Colorectal Surgery, King's College Hospital NHS Foundation Trust, Denmark Hill, London, U.K.

\begin{abstract}
Background/Aim: Transanal endoscopic microsurgery (TEMS) is emerging as an alternative treatment for rectal cancer Stage I. There remains a risk of local recurrence. The Aim of the study was to study the effect of biomarkers in local recurrence for Stage I rectal cancer following TEMS plus or minus radiotherapy. Materials and Methods: This is a case control study where we compared 10 early rectal cancers that had recurred, against 19 cases with no recurrence, total 29 patients (age $=28.25-86.87$, mean age $=67.92$ years, $S D=14.91$, Male, $N=18$, Female, $N=11)$. All patients underwent TEMS for radiological Stage I rectal cancer (yT1NOMO or yT2NOMO) established with combination of magnetic resonance imaging (MRI) and endorectal ultrasound. We prospectively collected all data on tumour histology, morphological features, as well as follow-up parameters. Molecular analysis was performed to identify their status on BRAF, KRAS, p16 $O^{6}$-methylguanineDNA methyltransferase (MGMT) and $\beta$-catenin. Results: Out of 29 specimens analyzed, 19 were KRAS wild type (65.9\%) and 10 mutant (34.5\%). Recurrence of the tumour was noted in 10 cases $(34.5 \%)$ from which $60 \%$ were pT1 $(N=6)$ and $40 \%$ pT2 $(N=4)$. There was a statistically significant association between KRAS mutant status and local recurrence $(N=6, p=0.037) . P 16$ expression greater than $5 \%$ (mean $=10.8 \%, \min =0, \max =95)$ is linked with earlier recurrence within 11.70 months $(N=7$, $p=0.004)$. Membranous $\beta$-catenin expression $(N=12,48 \%)$ was also related with KRAS mutant status $(p=0.006)$ but not with survival ( $p>0.05)$. BRAF gene was found to be wild type in all
\end{abstract}

This article is freely accessible online.

Correspondence to: Mr. Savvas Papagrigoriadis, Department of Colorectal Surgery, Hambleden Wing, 2nd Floor, King's College Hospital NHS Foundation Trust, Denmark Hill, SE5 9RS, London, U.K. Tel: +44 2032994667, e-mail: spapagrigoriadis@ nhs.net

Key Words: Colorectal cancer, biomarkers, transanal endoscopic microsurgery, KRAS, recurrence. cases tested ( $N=23)$. Conclusion: KRAS/p16/ $\beta$-catenin could be used as a combined biomarker for prediction of local recurrence and stratification of the risk for further surgery.

The method of local excision, that has recently, gained wider acceptance, in early rectal cancer, is transanal endoscopic microsurgery (TEMS). TEMS generally offers advantages in operative access and oncological clearance over transanal resection (TAR), but recently a number of similar logic techniques with various rectal ports for endoscopic excision of rectal tumours has been invented. Those methods are collectively named transanal minimal-invasive surgery (TAMIS) and for oncological purposes they share the same features of local excision as TEMS (1-14).

TEMS is a minimally invasive technique that was introduced by Buess in the early 1980's (2). Through the new rectoscope with $3 \mathrm{D}$ binocular optic and the endoscopic instruments, it offers better access to proximal lesions with lower margin positivity and fragmentation and magnification of the operative field $(2,15)$. TEMS is a safe procedure that offers low complication rates and peri-operative morbidity (10.7\%) (4). There have been multiple studies to suggest that TEMS is the operation of choice for rectal adenomas (1), retrorectal and submucosal rectal lesions (5). Furthermore, TEMS offers the advantage of not damaging the anorectal function (7).

TEMS is indicated as a curative treatment for malignant neoplasms that are histologically confirmed as pT1 sm1 carcinomas, whereas T1 sm2-3 and T2 lesions are still under question (8). A number of studies have shown that TEMS can have comparable results with radical surgery $(1,8,12$, 16) for rectal cancer.

There has been concern about oncologic outcomes following TEMS (17). Some studies support that there is potentially a higher risk of local recurrence rate with TEMS $(8,10,18)$. Efforts have been made to classify risk with morphological and histological criteria with better patients' selection (1, 6-9); however, the risk stratification remains 
imperfect. Molecular biomarkers have been used in prognosis of colorectal cancer (CRC) in general and rectal cancer seems to follow the same genetic phenotype (19). So far, data in the literature, that link biomarkers and oncologic outcomes from TEMS, are limited.

Several biomarkers are being studied in CRC. Nevertheless, rectal cancer may have a specific profile of biomarkers, which is different to the rest of colonic cancer (20). Kohonen-Corish et al. (20) went through and analyzed a cohort of 381 rectal cancer specimens. The conclusion was that they identified a more aggressive subgroup arising from the KRAS-p16 pathway. This was explained by the fact that p16 deficiency and KRAS mutant status did promote carcinogenesis through the loss of oncogene-induced senescence. Therefore, p16 and $K R A S$ could potentially be used as a prognostic biomarker in rectal cancer, which is against what is thought to be the case in sporadic colonic cancer.

We thus, aimed to identify whether any of the biomarkers $K R A S, B R A F, \mathrm{p} 16, \mathrm{MGMT}, \beta$-catenin could be used as a prognostic factor to predict recurrence in early rectal cancer following local excision (TEMS).

\section{Materials and Methods}

Our institution performs TEMS for early rectal cancer after discussion at the Multi-Disciplinary Cancer meeting (MDT) according to UK national guidelines. All cases in this study have been operated by the same surgeon (senior author, SP). We prospectively collected data on histological parameters of the each lesion i.e. stage, differentiation, location, margins of resection and dysplasia where applicable. Preoperative staging of the tumours has been performed with magnetic resonance imaging (MRI) of the rectum and endorectal ultrasound (EUS), which are proven to have high diagnostic accuracy when combined (21-24). We have an established follow-up protocol for these patients with an intensive 5-year surveillance consisting of 6 monthly endoscopy, carcinoembryonic antigen (CEA), MRI scan and computed tomography (CT) scan for 3 years, which is altered to annual surveillance in years 4 and 5 (Table I).

We selected 10 patients who had recurrence after TEMS for early rectal cancer and we compared them in a case control study with 19 similar patients without recurrence. This was to assure we could compare the status of several biomarkers in non recurrent vs. recurrent lesions. Eighteen patients $(62.1 \%)$ were male and $37.8 \%$ were female $(\mathrm{N}=11)$. Mean age at the stage of diagnosis, was 67.93 years $(\min =28.25, \max =86.87)$. All the specimens were Stage I rectal cancer. Eighteen were pT1 (62.1\%) and 11 pT2 (37.9\%). There were no differences between the two groups.

Radiological staging has been performed both before and after radiotherapy. Neoadjuvant or adjuvant radiotherapy decision was based on fitness criteria, as well as patient choice. The option of further radical (completion) surgery has been offered in selected individualised cases as an option but was declined by the patients.

Biomarker analysis. All biomarkers were assessed on formalin-fixed, paraffin -embedded (FFPE) samples. Beta-catenin, mismatch repairs (MMRs), $\mathrm{O}^{6}$-methylguanine-DNA methyltransferase (MGMT) and p16 assays were performed using immuno-histochemistry (IHC). Four- $\mu \mathrm{M}$ sections of the tumour were cut on to coated slides and IHC was performed using standardised protocols for each antibody. The final step was visualisation of antigen-antibody complexes by the addition of the chromogen, diaminobenzidine. The slides were then assessed (by SDC and JM) and scored for percentage of positive tumour cells and protein location (Figures 1-5).

$K R A S$ mutation analysis was performed on the same tumour samples. Haematoxylin and eosin (H\&E) stained sections of the tumour were assessed and marked for tumour content and the tumour was then macrodissected using serial, unstained section from the non-tumour components, allowing for enrichment of tumour cells. DNA was then extracted from these samples using standardised protocols and quantified by Qubit analysis. Polymerase chain reaction (PCR) using primers either side of the regions of interest, codons 12 and 13 and codon 61, was performed. After immobilisation of the resulting amplicons, single stranded DNA was prepared and the sequencing primer for each region was annealed. The samples were then analysed on a Qiagen Q24 pyrosequencer ${ }^{\odot}$, using the appropriate software (PyroMark Q24 software, version 2.07). The mutation status of each tumour was reported according to standard protocols (by SDC and JM).

Appropriate positive and negative controls were included for all assays. Photos have been obtained by JM with the relevant permission of Advanced Diagnostics Laboratory (King's Hospital NH Foundation Trust, London, Denmark Hill, UK).

Statistical analysis. Statistical analysis of our results was performed using IBM SPSS for Macintosh version 22 (IBM Corp., Armonk, NY, USA). We have performed bivariate correlations (Pearson's and Spearman's rho, as well as Chi-square associations) to identify any potential links between follow-up parameters and KRAS, BRAF, p16, $\beta$-catenin or MGMT.

\section{Results}

The mean overall follow-up period was 32.83 months $(\mathrm{SD}=23.02, \min =12.96, \max =126.9)$. From 29 patients, 19 did not have recurrence $(65.5 \%)$, whereas 10 did have local recurrence of the rectal lesion $(34.5 \%)$. The mean recurrence time was 13.04 months $(\min =4.11, \max =42.28)$ (Table I).

From 29 patients, $79.3 \%(\mathrm{~N}=23)$ did not require further surgery, whereas $21.6 \%$ did $(\mathrm{N}=6)$. Twenty-five patients warranted TEMS procedure once $(86 \%)$, whereas 1 patient required TEMS procedure twice $(3.4 \%), 1$ three times $(3.4 \%)$ and 2 four times $(6.8 \%)$. Decision to proceed with multiple TEMS was based on the fact that patients were unfit for radical surgery. Three patients $(10.3 \%)$ received neoadjuvant radiotherapy $(\mathrm{N}=1$ was $\mathrm{pT} 1$ and $\mathrm{N}=2 \mathrm{pT} 2)$, whereas $89.7 \%$ $(\mathrm{N}=26)$ did not receive. $\mathrm{N}=9$ received further course of radiotherapy, based on the histology findings of unsuspected cancer and individualized decision to proceed with radiotherapy was made by the Multidisciplinary Team Meeting. Patients underwent short course radiotherapy; the regimen was 45-50Gy according to the local guidelines. All patients who had repeat TEMS surgery were elderly or unfit for major surgery and, therefore, the procedure was palliative (Table I). 
Table I. Patients' characteristics, specimens' morphology, biomarkers' profile.

\section{Cohort details}

Age (diagnosis)

Follow-up

Recurrence

Clear margins

Number of TEMS

Yes, $\mathrm{N}=10(34.5 \%)$

Mean age $=67.92(28.25-86.87)$ years

Mean follow-up=32.83 (12.96-126.9) months

Mean Recurrence=13.04 (4.11-42.28) months

Yes $\mathrm{N}=20(69 \%)$
Inconclusive $\mathrm{N}=10(31 \%)$
Times $\times 2$

$\mathrm{N}=1(3.4 \%)$
Times $\mathrm{x} 3$

$\mathrm{N}=3(3.4 \%)$
Times $\mathrm{x} 4$

$\mathrm{N}=2(6.8 \%)$

Tumours' Features

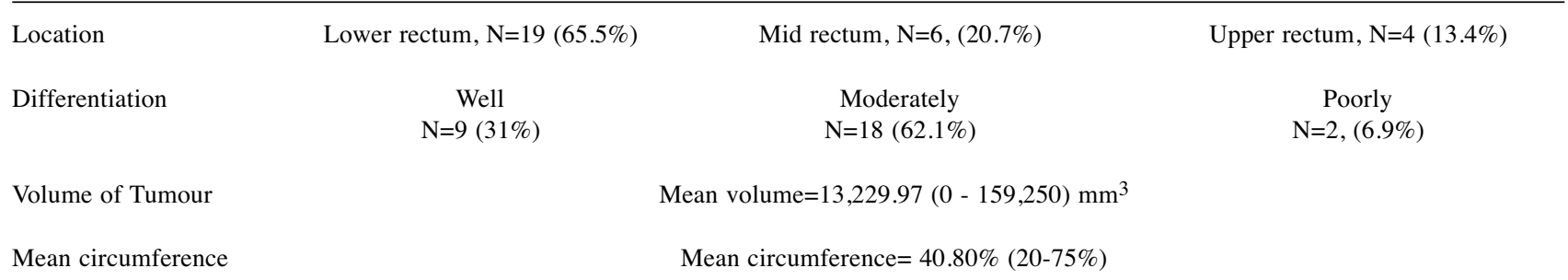

Additional radiotherapy (Neo-adjuvant or adjuvant)

\begin{tabular}{|c|c|c|c|c|}
\hline Neo-adjuvant radiotherapy & \multicolumn{2}{|c|}{ Yes, $\mathrm{N}=3(10.3 \%)$} & \multicolumn{2}{|c|}{ No, $\mathrm{N}=26(89.7 \%)$} \\
\hline Adjuvant radiotherapy & \multicolumn{2}{|c|}{ Yes, $\mathrm{N}=9(31 \%)$} & \multicolumn{2}{|c|}{ No, $\mathrm{N}=20(69 \%)$} \\
\hline \multicolumn{5}{|c|}{ Biomarkers } \\
\hline KRAS & \multicolumn{2}{|c|}{$\begin{array}{c}\text { Wild-type } \\
\mathrm{N}=19(65.5 \%)\end{array}$} & \multicolumn{2}{|c|}{$\begin{array}{c}\text { Mutant } \\
\mathrm{N}=10(34.5 \%)\end{array}$} \\
\hline$B R A F$ & \multicolumn{4}{|c|}{ All analyzed specimens $(\mathrm{N}=23)$ were BRAF wild-type } \\
\hline MGMT & \multicolumn{2}{|c|}{ Preserved, $\mathrm{N}=23(91 \%)$} & \multicolumn{2}{|c|}{ Non-preserved, $\mathrm{N}=2(9 \%)$} \\
\hline$\beta$-catenin & $\begin{array}{l}\text { Membranous } \\
\mathrm{N}=12(48 \%)\end{array}$ & $\begin{array}{c}\text { Membranous }+30 \% \text { nucleus } \\
\mathrm{N}=7(30 \%)\end{array}$ & $\begin{array}{c}\text { Membranous }+50 \% \text { nucleus } \\
\mathrm{N}=3,(10.3 \%)\end{array}$ & $\begin{array}{c}\text { Nucleus } \\
\mathrm{N}=3,(10.3 \%)\end{array}$ \\
\hline P16 & \multicolumn{4}{|c|}{ Mean expression $=10.8 \%(0-75 \%)$} \\
\hline
\end{tabular}

All the 29 specimens were Stage I out of which $62.1 \%$ were pT1N0 $(\mathrm{N}=18)$ and $37.9 \%$ were pT2N0 $(\mathrm{N}=11)$. This is based on radiological criteria. Completion of staging was performed with the rest of preoperative work up, including EUS, clinical assessment, CT abdomen-pelvis-thorax (TAP) and MRI of the pelvis and rectum. Almost one third (31.0\%) did not have confirmed clear resection margins $(\mathrm{N}=9)$, whereas in the rest $69 \%$ $(\mathrm{N}=20)$, the margins were confirmed to be clear. The remaining tumours had margins obscured by the energy device artefact
(Harmonic Ace and electro cautery) and were declared uncertain. There were no positive margins. Nineteen lesions $(65.5 \%)$ were located in the lower rectum, $20.7 \%(\mathrm{~N}=6)$ in the mid rectum and $13.4 \%(\mathrm{~N}=4)$ in the upper rectum. Two $(6.9 \%)$ were poorly differentiated adenocarcinomas, whereas $62.1 \%(\mathrm{~N}=18)$ were moderate differentiated and $31 \%(\mathrm{~N}=9)$ were well differentiated. The mean circumference of the tumour was $40.80 \%$ ( $\mathrm{min}=20 \%$, $\max =75 \%$ ). Greater than $33 \%$ circumference was found to be linked with mutant KRAS $(p=0.00)$ (Table II). 


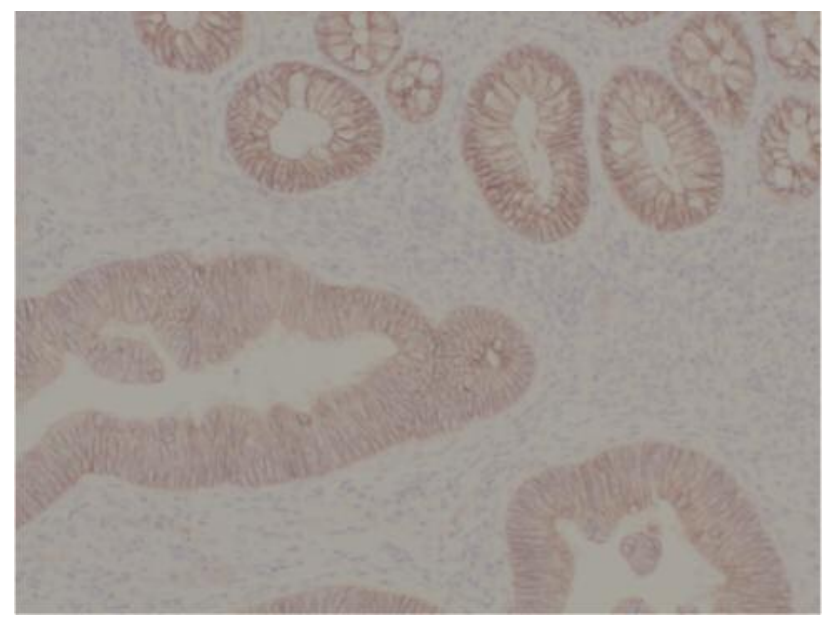

Figure 1. Beta-catenin membranous. Original photo from KCH lab (J. Moorhead).

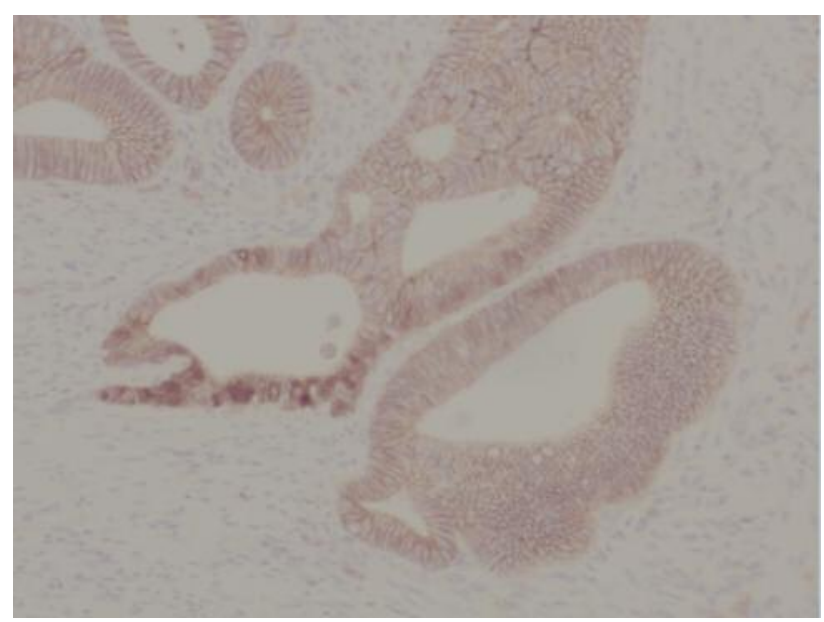

Figure 2. Beta-catenin membranous and nuclear. Original photo from KCH lab (J. Moorhead).

Nineteen of the specimens were KRAS wild type (65.5\%) whereas $34.5 \%(\mathrm{~N}=10)$ were $K R A S$ mutant (codon 12,13 or 61 ). From the available $B R A F$ results, 23 of the specimens were analysed and none was found to be positive for V600E mutation (wild type). From the MGMT point of view, $91 \%$ $(\mathrm{N}=23)$ were positive (preserved), whereas $8 \%(\mathrm{~N}=2)$ were negative (non-preserved). Four patients did not have available MGMT status (Table II).

From 29 specimens, 25 had available $\beta$-catenin status. Almost half (48\%) were found to express membranous (m) status of $\beta$-catenin $(\mathrm{N}=12)$ (Figure 1$)$, whereas $28 \%$ was found to express membranous and $30 \%$ nucleus $(\mathrm{n})(\mathrm{N}=7)$ (Figure 2$), 10.3 \% \mathrm{~m}+50 \% \mathrm{n}(\mathrm{N}=3)$ and $10.3 \%$ only nucleus $(\mathrm{N}=3)$. All KRAS mutant tumours were linked with

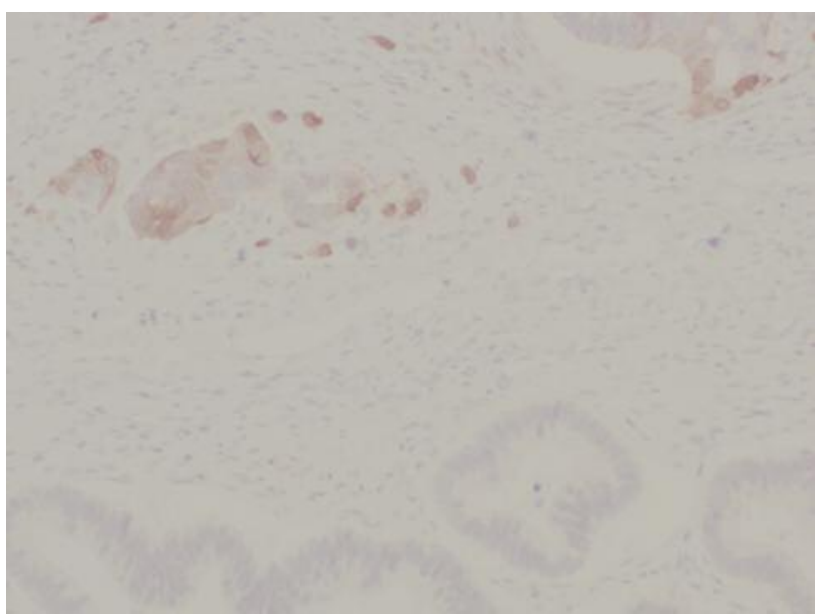

Figure 3. P16 expression. Original photo from KCH lab (J. Moorhead).

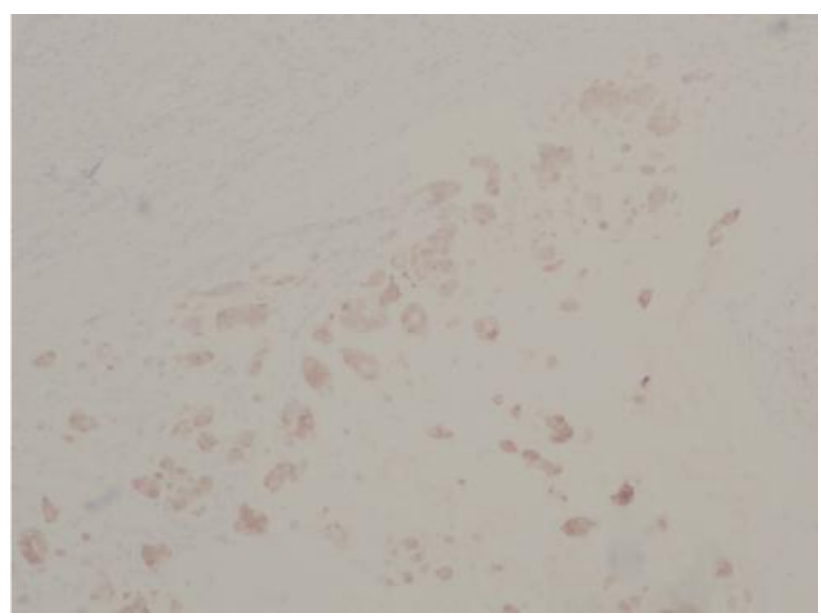

Figure 4. P16 expression (higher \%). Original photo from KCH lab (J. Moorhead).

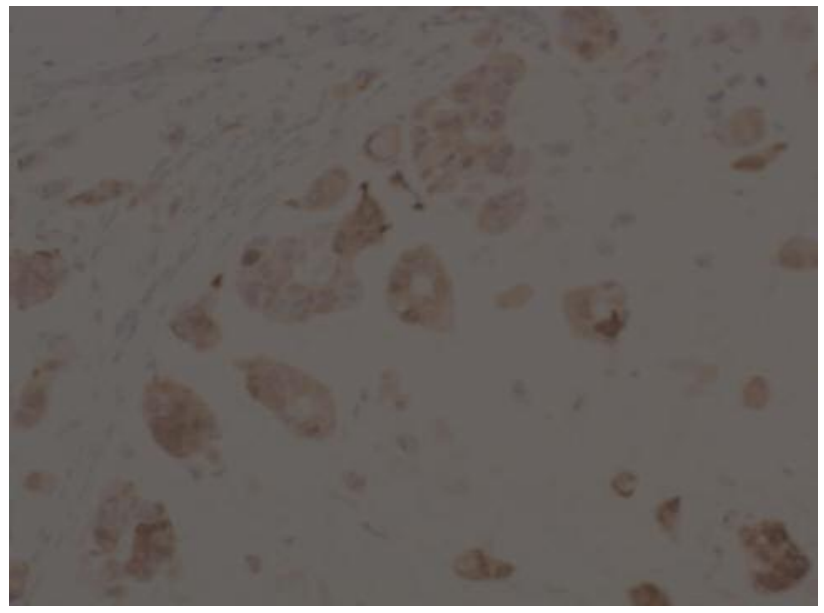

Figure 5. P16 expression. Original photo from KCH lab (J. Moorhead). 


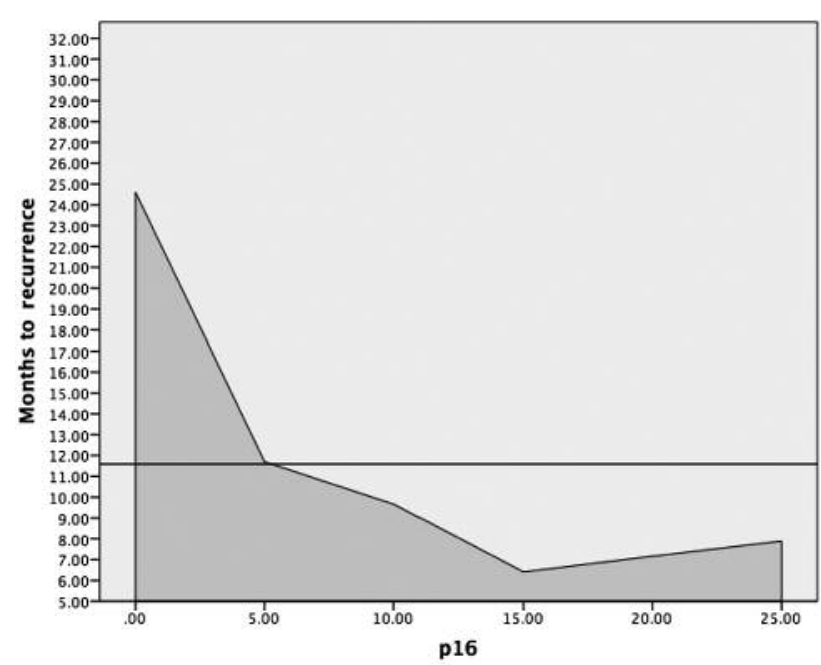

Figure 6. Circumference vs. $\beta$-catenin expression.

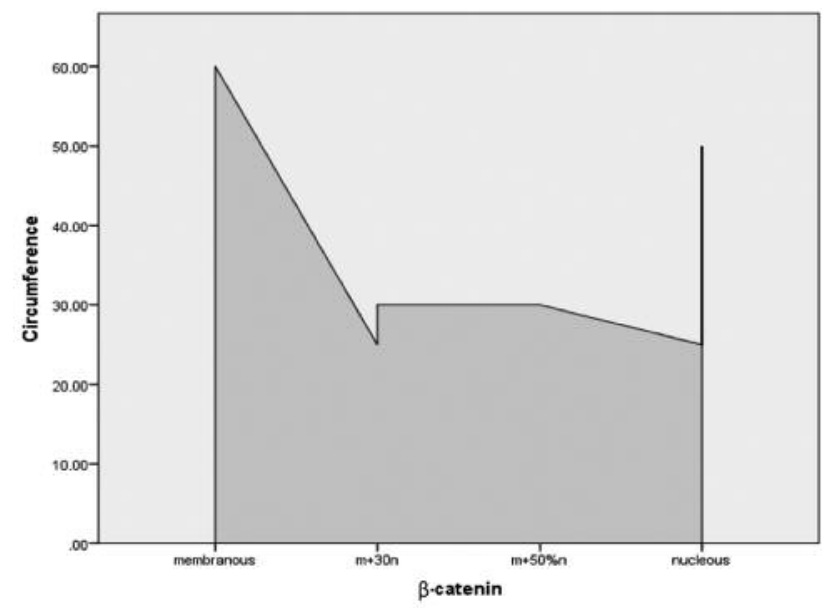

Figure 7. P16 in relationship with time of recurrence.

membranous $\beta$-catenin $(\mathrm{N}=8, p=0.009)$, whereas wild-type KRAS were spread between $\beta$-catenin $\mathrm{m}(\mathrm{N}=3,23.1 \%)$, $\mathrm{m}+30 \% \mathrm{n}(\mathrm{N}=7,53.8 \%), \mathrm{m}+50 \% \mathrm{n}(\mathrm{N}=3,15.2 \%)$ and $100 \% \mathrm{n}$ $(\mathrm{N}=1,7.6 \%)$. Also membranous $\beta$-catenin was linked with more circumferential configuration of the tumour $(p=0.028)$ but not with survival ( $p>0.05$ ) (Figure 6).

From our primary analysis, there was an association between mutant KRAS and local recurrence $(p=0.037)$. From 10 specimens, which recurred, $60 \%$ were mutant for KRAS ( $\mathrm{N}=6)$ and $40 \%$ wild type $(\mathrm{N}=4)$. Also, from 19 specimens with no recurrence, $79 \%(\mathrm{~N}=15)$ were wild type and $21 \%(\mathrm{~N}=4)$ KRAS mutant (Table III). There was no association between recurrence and p16 or $\beta$-catenin or MGMT status $(p>0.05)$. Furthermore, local recurrence was not found to be associated with MRI pT stage, $(p>0.05)$ or other morphological features of the tumour, including height, location, circumference and orientation $(p>0.05)$. Local recurrence was not found to be associated with histological features of the specimens, i.e. pT stage, clear margins, dysplasia or differentiation $(p>0.05)$. Moreover, there was no association between recurrence and neoadjuvant radiotherapy $(p=0.123)$ (Table II).

The overall mass was calculated from the dimensions documented on the histology report (size 1 in $\mathrm{mm} \times$ size 2 in $\mathrm{mm} \times$ size 3 in $\mathrm{mm}$ ). The overall mean mass of the specimens was $13,229.967 \mathrm{~mm}^{3} \min =0.00 \mathrm{~mm}^{3}$, $\max =159,250.00 \mathrm{~mm}^{3}, \mathrm{SD}=28,706.9$. The mean mass of the tumours that recurred was $25,776 \mathrm{~mm}^{3}\left(\min =3,200 \mathrm{~mm}^{3}\right.$ $\left.\max =159,250 \mathrm{~mm}^{3}, \mathrm{SD}=47,375\right)$ compared to $6,626 \mathrm{~mm}^{3}$ $\left(\min =00 \mathrm{~mm}^{3}, \max =17,940 \mathrm{~mm}^{3}, \mathrm{SD}=5,121\right)$ for those that did not recur. There was a statistical significant relationship between the mass and recurrence of the lesions $(p=0.028)$.

$K R A S$ was found to be associated with $\beta$-catenin status $(p=0.009)$ and, more specifically, mutant KRAS tends to be linked with membranous $\beta$-catenin $(\mathrm{N}=12,41.9 \%)$. Also, $K R A S$ mutant status is associated with the increased number of total TEMS $(p=0.02)$. All wild-type KRAS $(\mathrm{N}=19)$ specimens have undergone a single operation, whereas $11.1 \%(\mathrm{~N}=1)$ of mutant had times 2 TEMS, $11.1 \%(\mathrm{~N}=1)$ times 3 and $22.2 \%(\mathrm{~N}=2)$ times 4 . What is more, cancerrelated death was noted in $6.9 \%(\mathrm{~N}=2)$ and was linked with KRAS mutant status $(p=0.045)$. Discovery of unsuspected cancer was noted in $41.3 \%(\mathrm{~N}=12)$ and linked with mutant $K R A S(\mathrm{~N}=7, p=0.023)$. However, there was no link between $K R A S$ and dysplasia or differentiation of the specimen or clear margins or mass or pT stage or orientation of the specimen ( $p>0.05$ for all associations, Table II).

Mean $\mathrm{p} 16$ expression was $10.8 \%(\min =0.0 \%, \max =75 \%)$. P16 expression more than 5\% was linked with recurrence within the first 11.70 months $(\mathrm{N}=7, p=0.04)$ (Figure 7), though no other histological, morphological or phenotype association was identified ( $p>0.05$ ) (Table II) (Figures 3-5).

Finally, MGMT status was found preserved in $92.0 \%(\mathrm{~N}=23)$ and non-preserved (negative) in $8.0 \%(\mathrm{~N}=2)$. All patients with MGMT negative results were aged above 80 years at the time of diagnosis $(p=0.024)$ and pT2 $(p=0.030)$. There was no other association noted between MGMT and morphological, histological or follow-up parameters $(p>0.05)$ (Table II).

\section{Discussion}

There has long been an effort to link molecular biomarkers with prognosis in colorectal cancer but it still remains a poorly understood field. From our data, there seems to be a link 
Table II. Significant associations.

\begin{tabular}{|c|c|c|c|c|c|c|}
\hline & \multirow[b]{2}{*}{$\mathrm{F}$} & \multicolumn{2}{|c|}{$K R A S$} & \multicolumn{2}{|c|}{ Recurrence } & \multirow[t]{2}{*}{ Other association } \\
\hline & & Wild type & Mutant & Yes & No & \\
\hline \multirow[t]{2}{*}{ P16 } & $0-75 \%$ & $0-40 \%$ & $0-80 \%$ & $0-30 \%$ & $0-80 \%$ & $>5 \% \rightarrow$ recurrence \\
\hline & Mean $=10.8 \%$ & $p=0.258$ & $p=0.258$ & $p=0.761$ & $p=0.761$ & in 10 months $(p=0.04)$ \\
\hline \multirow[t]{2}{*}{$\beta$-catenin } & NA & any & $\begin{array}{c}\text { Membranous } \\
\mathrm{N}=8\end{array}$ & $\begin{array}{c}\mathrm{m} \& \mathrm{~m}+30 \mathrm{n} \\
p=0.724\end{array}$ & $\begin{array}{c}\text { Any } \\
p=0.724\end{array}$ & $\begin{array}{l}\text { Higher circumference } \\
\qquad(p=0.028)\end{array}$ \\
\hline & & & $p=0.009$ & & & \\
\hline \multirow[t]{2}{*}{ MGMT } & $\mathrm{P}(\mathrm{N}=23)$ & $\mathrm{P}(\mathrm{N}=15)$ & $\mathrm{P}(\mathrm{N}=8)$ & $\mathrm{P}(\mathrm{N}=8)$ & $\mathrm{P}(\mathrm{N}=15)$ & All NP were 80 years \\
\hline & $\mathrm{NP}(\mathrm{N}=2)$ & $\begin{array}{c}\mathrm{NP}(\mathrm{N}=1) \\
p=0.683\end{array}$ & $\begin{array}{c}\mathrm{NP}(\mathrm{N}=1) \\
p=0.683\end{array}$ & $\begin{array}{c}\mathrm{NP}(\mathrm{N}=1) \\
p=0.683\end{array}$ & $\begin{array}{l}\mathrm{NP}(\mathrm{N}=1) \\
p=0.683\end{array}$ & $\begin{array}{c}\text { old and above } \\
p=0.024 \text { and } \mathrm{pT} 2, p=0.030\end{array}$ \\
\hline \multirow[t]{4}{*}{ Differentiation } & $\mathrm{W}(\mathrm{N}=9)$ & $\mathrm{W}(\mathrm{N}=7)$ & $\mathrm{W}(\mathrm{N}=3)$ & W (4) & $\mathrm{W}(\mathrm{N}=5)$ & NA \\
\hline & $M(N=18)$ & $\mathrm{M}(\mathrm{N}=11)$ & $M(N=7)$ & $M(6)$ & $\mathrm{M}(\mathrm{N}=12)$ & \\
\hline & $\mathrm{P}(\mathrm{N}=2)$ & $\mathrm{P}(\mathrm{N}=2)$ & $\mathrm{P}(\mathrm{N}=0)$ & $\mathrm{P}(0)$ & $\mathrm{P}(\mathrm{N}=2)$ & \\
\hline & & $p=0.774$ & $p=0.774$ & $p=0.317$ & $p=0.317$ & \\
\hline \multirow[t]{4}{*}{ Dysplasia } & $\mathrm{H}(\mathrm{N}=5)$ & $\mathrm{H}(\mathrm{N}=2)$ & $\mathrm{H}(\mathrm{N}=3)$ & $\mathrm{H}(\mathrm{N}=3)$ & $\mathrm{H}(\mathrm{N}=2)$ & NA \\
\hline & $\mathrm{M}(\mathrm{N}=1)$ & $\mathrm{M}(\mathrm{N}=0)$ & $\mathrm{M}(\mathrm{N}=1)$ & $M(N=0)$ & $\mathrm{M}(\mathrm{N}=1)$ & \\
\hline & $\mathrm{NA}(\mathrm{N}=23)$ & $\mathrm{NA}(\mathrm{N}=17)$ & $\mathrm{NA}(\mathrm{N}=6)$ & $\mathrm{NA}(\mathrm{N}=7)$ & $\mathrm{NA}(\mathrm{N}=16)$ & \\
\hline & & $p=0.057$ & $p=0.057$ & $p=0.445$ & $p=0.445$ & \\
\hline \multirow[t]{4}{*}{ Location } & $\mathrm{L}(\mathrm{N}=19)$ & $\mathrm{L}(\mathrm{N}=12)$ & $\mathrm{L}(\mathrm{N}=8)$ & $\mathrm{L}(\mathrm{N}=7)$ & $\mathrm{L}(\mathrm{N}=12)$ & \\
\hline & $M(N=6)$ & $\mathrm{M}(\mathrm{N}=4)$ & $p=0.177$ & $\mathrm{M}(\mathrm{N}=2)$ & $\mathrm{M}(\mathrm{N}=4)$ & NA \\
\hline & $\mathrm{U}(\mathrm{N}=4)$ & $\mathrm{U}(\mathrm{N}=3)$ & & $\mathrm{U}(\mathrm{N}=1)$ & $\mathrm{U}(\mathrm{N}=3)$ & \\
\hline & & $p=0.177$ & & $p=0.690$ & $p=0.690$ & \\
\hline \multirow[t]{3}{*}{ Clear margins } & $\mathrm{Y}(\mathrm{N}=20)$ & $\mathrm{Y}(\mathrm{N}=14)$ & $\mathrm{Y}(\mathrm{N}=6)$ & $\mathrm{Y}(\mathrm{N}=6)$ & $\mathrm{Y}(\mathrm{N}=14)$ & NA \\
\hline & $\mathrm{N}(\mathrm{N}=9)$ & $\mathrm{N}(\mathrm{N}=5)$ & $\mathrm{N}(\mathrm{N}=4)$ & $\mathrm{N}(\mathrm{N}=4)$ & $\mathrm{N}(\mathrm{N}=5)$ & \\
\hline & & $p=0.467$ & $p=0.467$ & $p=0.467$ & $p=0.467$ & \\
\hline \multirow[t]{3}{*}{ pT stage } & pT1 $(\mathrm{N}=18)$ & pT1 $(\mathrm{N}=11)$ & pT1 $(\mathrm{N}=7)$ & pT1 $(\mathrm{N}=6)$ & pT1 $(\mathrm{N}=12)$ & NA \\
\hline & pT2 $(\mathrm{N}=11)$ & pT2 $(\mathrm{N}=8)$ & pT2 $(\mathrm{N}=3)$ & pT2 $(\mathrm{N}=4)$ & pT2 $(\mathrm{N}=6)$ & \\
\hline & & $p=0.540$ & $p=0.540$ & $p=0.873$ & $p=0.873$ & \\
\hline \multirow[t]{5}{*}{ MRI pT stage } & pT0 $(\mathrm{N}=3)$ & pT0 $(\mathrm{N}=3)$ & pT0 $(\mathrm{N}=0)$ & pT0 $(\mathrm{N}=0)$ & pT0 $(\mathrm{N}=3)$ & NA \\
\hline & pT1 $(\mathrm{N}=7)$ & PT1 $(\mathrm{N}=4)$ & pT1 $(\mathrm{N}=3)$ & pT1 $(\mathrm{N}=3)$ & pT1 $(\mathrm{N}=4)$ & \\
\hline & pT2 $(\mathrm{N}=9)$ & pT2 $(\mathrm{N}=6)$ & pT2 $(\mathrm{N}=3)$ & pT2 $(\mathrm{N}=3)$ & pT2 $(\mathrm{N}=6)$ & \\
\hline & pT3 $(\mathrm{N}=4)$ & pT3 $(\mathrm{N}=2)$ & pT2 $(\mathrm{N}=2)$ & pT3 $(\mathrm{N}=2)$ & pT3 $(\mathrm{N}=2)$ & \\
\hline & & $p=0.390$ & $p=0.390$ & $p=0.390$ & $p=0.390$ & \\
\hline \multirow[t]{2}{*}{ Circumference } & $20-75 \%$ & $20-50 \%$ & $30-80 \%$ & $20-80 \%$ & $20-70 \%$ & NA \\
\hline & Mean $=40.80 \%$ & $p=0.00$ & $p=0.00$ & $p=0172$ & $p=0.172$ & \\
\hline \multirow[t]{2}{*}{ Age } & $28.25-86.87$ & Any & Any above 60 & Any above 30 & Any & NA \\
\hline & Mean $=67.93$ & $p=0.109$ & $p=0.109$ & $p=0.338$ & $p=0.338$ & \\
\hline \multirow[t]{2}{*}{ Mass } & $0-159.250$ & $>17940$ & $>159.250$ & $>17940$ & $>159.250$ & NA \\
\hline & Mean $=13229.97$ & $p=0.073$ & $p=0.073$ & $p=0.028$ & $p=0.028$ & \\
\hline \multirow[t]{3}{*}{ Gender } & $\mathrm{M}(\mathrm{N}=18)$ & $\mathrm{M}(\mathrm{N}=9)$ & $\mathrm{M}(\mathrm{N}=9)$ & $\mathrm{M}(\mathrm{N}=8)$ & $\mathrm{M}(\mathrm{N}=10)$ & NA \\
\hline & $\mathrm{F}(\mathrm{N}=11)$ & $\mathrm{F}(\mathrm{N}=10)$ & $\mathrm{F}(\mathrm{N}=1)$ & $\mathrm{F}(\mathrm{N}=2)$ & $\mathrm{F}(\mathrm{N}=9)$ & \\
\hline & & $p=0.024$ & $p=0.024$ & $p=0.160$ & $p=0.160$ & \\
\hline \multirow[t]{3}{*}{ Cancer-related death } & $\mathrm{Y}(\mathrm{N}=2)$ & $\mathrm{Y}(\mathrm{N}=0)$ & $\mathrm{Y}(\mathrm{N}=2)$ & $\mathrm{Y}(\mathrm{N}=2)$ & $\mathrm{Y}(\mathrm{N}=0)$ & NA \\
\hline & $\mathrm{N}(\mathrm{N}=27)$ & $\mathrm{N}(\mathrm{N}=19)$ & $\mathrm{N}(\mathrm{N}=8)$ & $\mathrm{N}(\mathrm{N}=8)$ & $\mathrm{N}(\mathrm{N}=19)$ & \\
\hline & & $p=0.045$ & $p=0.045$ & $p=0.045$ & $p=0.045$ & \\
\hline
\end{tabular}

Table III. KRAS and local recurrence.

\begin{tabular}{|c|c|c|c|c|}
\hline \multirow[t]{2}{*}{$K R A S$ status } & \multicolumn{2}{|c|}{ Recurrence } & \multirow{2}{*}{$\begin{array}{c}\text { Significance } \\
\text { Total }\end{array}$} & \\
\hline & YES & $\mathrm{NO}$ & & \\
\hline Wild type & $\mathrm{N}=4(13.8 \%)$ & $\mathrm{N}=15(51.7 \%)$ & $\mathrm{N}=19(65.5 \%)$ & $p=0.037$ \\
\hline Mutant & $\mathrm{N}=6(20.7 \%)$ & $\mathrm{N}=4(13.8 \%)$ & $\mathrm{N}=10(34.5 \%$ & $p=0.037$ \\
\hline Total & $\mathrm{N}=10(34.5 \%)$ & $\mathrm{N}=19(65.5 \%)$ & $\mathrm{N}=29(100 \%)$ & \\
\hline
\end{tabular}


between mutant $K R A S$ and the risk of local recurrence of early rectal cancer after endoscopic local excision surgery TEMS. This is a previously unreported finding. We discuss here whether there may be a sound biological basis of this finding.

Kirstein rat sarcoma viral sarcoma oncogene $(K R A S)$, is a proto-oncogene involved in cellular response to extracellular stimuli, i.e. mitogen-activated protein kinase (MAPK) and phosphoinositide-3-kinase/v-akt murine thymoma viral oncogene pathways (PI3K/AKT) $(25,26)$. Therefore, KRAS mutations can potentially lead to activation of downstream signaling pathways, i.e. MAPK and PI3K/AKT. The latter is thought to lead to a higher resistance to anti-epidermal growth factor receptor (EGFR) inhibitors and, hence, this could be the etiology for increased resistance to anti-EGFR chemotherapy agents $(27,28)$.

KRAS mutations in codons 12,13 and 61 are the most popular and tend to occur in $30-40 \%$ of CRCs. However, there have been noted 85 different KRAS mutations, many of which refer to a specific cancer pathway $(8,29)$.

So far, the prognostic and predictive value of KRAS gene in $\mathrm{CRC}$ has been debated, though it still remains controversial. There have been studies, which mainly support KRAS predictive value in response to anti-EGFR chemotherapy agents (27). More specifically, wild type $K R A S$ is thought to be linked with better response to antiEGFR agents, i.e. cetuximab, and this could be attributed to the relevant molecular mechanism described in the previous paragraph (28). Nevertheless, there are emerging data that $K R A S$ predictive value in response to anti-EGFR inhibitors is controversial when $B R A F$ gene appears to be mutant (V600E mutation) (30-32).

On the contrary, the prognostic value of KRAS in CRC remains equivocal. Most of the studies are inconclusive (29, 33 ) but there are some that associate KRAS mutant status with poorer prognosis (34).

Our study concludes that mutant KRAS may create a higher risk of local recurrence of early rectal cancer following TEMS. In our data, there is no association between local recurrence and pT stage or any other histopathological features $(p>0.05)$; however, we need to keep in mind this is a small study not powered enough to test all possible factors. A recent study (35) supports that the frequency of KRAS mutant colorectal carcinomas is $35-40 \%$, where in our case is $34.5 \%$.

$K R A S$ is also linked with some morphological features of the tumors and this can support its impact on the recurrence (35). Given the fact that a change in the genotype can directly reflect on the tumor phenotype, we can support that $K R A S$ is linked with more circumferential configuration $(p=0.000)$ and height of the lesion $(p=0.030)$, as well as bigger mass $(p=0.029)$.

$B R A F$ V600E seems to be another valid prognostic biomarker in CRC. There is a link between $B R A F$ V600E status and worse prognosis $(36,37)$ and $B R A F$ V600E and more advanced cancer, being mostly present in right-sided tumours $(38,39)$. As discussed before, BRAF V600E has been found to interfere with KRAS occasionally. There are studies supporting that mutant $B R A F$ status can affect response to anti-EGFR chemotherapy agents even in the presence of wild type $K R A S(40,41)$. All our specimens were BRAF wild type, where tested, and this could be explained by both the location, as well as earlier stage.

Another interesting finding in our data, is that p16 and MGMT are associated with older age $(p=0.01$ and $p=0.024$, respectively). Methylation of $\mathrm{CpG}$ islands $(\mathrm{CpG}$ island methylator phenotype (CIMP) and, specifically, O6methylguanine-DNA methyltransferase (MGMT) gene promoter methylation) has been studied extensively in CRC $(42,43)$ and seems to have a recognized impact on the carcinogenesis pathway, though there is no consensus about its prognostic value (44). Loss of MGMT expression is found in $30-40 \%$ of metastatic CRC and results in the inability of the alkyl base to be removed from the methylated guanine and, hence, preservation of the DNA is not achieved (44).

With regards to the prognostic value of $\mathrm{p} 16$, there are studies correlating the methylation of $\mathrm{p} 16$ promoter with several clinicopathological features of CRC (45), i.e. TNM stage $(p=0.006)$, lymph node metastasis $(p=0.002)$, histologic grade $(p<0.001)$, Dukes stage $(p=0.002)$, tumour size $(p=0.041)$ and location $(p<0.001)$ Also, another study (46) shows that $\mathrm{p} 16$ methylation is found more in the serum of metastatic CRC patients. On our study, there is a link between p16 expression $>5 \%$ and recurrence within 11.5 months $(p=0.04)$. Furthermore, a recent cohort study (47) concludes that patients with advanced CRC, p16, human mutL homolog 1 (hMLH1) and MGMT methylation are associated with higher risk of recurrence, compared to patients with preserved unmethylated promoters.

Another interesting recent study (48) concludes that approximately $70 \%$ of $K R A S$-positive tumors are thought to have a CIMP characterized by aberrant methylation of the DNA of multiple genes, including p14, p15, p16. Therefore, this could be used as a link between $K R A S$ status and p16 expression, especially in different stages of the cancer pathway.

In terms of the $\beta$-catenin significance, there seems to be a link between KRAS mutant status and membranous $\beta$-catenin $(\mathrm{N}=8, p=0.09)$. This is fairly interesting as it connects two different pathways of the carcinogenesis pathway together. Beta-catenin seems to belong to a different signalling pathway (wnt/ $\beta$-catenin) and its significance in $\mathrm{CRC}$ remains equivocal. Beta-catenin is a pivotal molecule involved in intercellular adhesion and some other oncogenic and developmental processes (49). The same study links the up-regulation of $\beta$-catenin with the confrontation of tumour cells in the host microenvironment, whilst in metastatic 
process. However, its role in CRC remains unclear. In our study, membranous $\beta$-catenin is linked with higher circumference of the tumor $(p=0.028$, Figure 6). This supports again a joint role with mutant KRAS status as the latter is linked with higher circumference as well. An interesting study (50) in lung cancer concludes that combinational activation of $K R A S$ and wnt/ $\beta$-catenin pathway leads to a significant increase on the lung tumour formation and, therefore, worse prognosis effect.

With regards to the decision for further neoadjuvant radiotherapy, no relationship was identified between the decision for neoadjuvant radiotherapy and our potential biomarkers, i.e. KRAS, BRAF, MGMT, $\beta$-catenin and p16 ( $p>0.05$ for all associations).

On the other hand, we still recognize some limitations of our study, mainly due to small sample size of our cohort. Nevertheless, as recurrence early rectal cancer after local excision is rare, with average numbers around $10 \%$, it is not easy to form a much larger study than this. However, we consider our findings adequate to propose that KRAS, p16 expression and $\beta$-catenin status should be looked further as a potential combined biomarker system to assess the risk of local recurrence. Mutant KRAS was found to be more associated with local recurrence and with unsuspected cancer in the specimen $(p=0.023)$ (when the initial tumor was thought dysplastic). Membranous $\beta$-catenin tends to be linked with mutant KRAS as well. P16 expression is associated with earlier recurrence, something that could redirect the focus of the 5-year postoperative surveillance protocol if confirmed.

In conclusion, the biomarkers $K R A S / \mathrm{p} 16 / \beta$-catenin could be used as a combined biomarker for prediction of local recurrence and stratification of the risk for further surgery. Further research based on multicentre cohort samples, should be conducted to confirm these findings, and improve our understanding on the actual effect of those biomarkers in the recurrence of early rectal cancer, after local excision.

\section{Funding}

Internal (Departmental) funding was used to support this project, Part of MD(Res) Thesis at King's College London.

\section{Conflicts of Interest}

The Authors declare no conflict of interest.

\section{References}

1 Guerrieri M, Baldarelli M, Rimini M, Gesuita R, Lezoche G, Romiti $\mathrm{C}$ and Lezoche E: Transanal endoscopic microsurgery for rectal tumors: An option to radical surgery? Minerva Chir 68(3): 289-298, 2013.
2 Lezoche G, Paganini AM, Campagnacci R, Ghiselli R, Pelloni M, Rombini A and Guerrieri M: Treatment of rectal cancer by transanal endoscopic microsurgery: Review of the literature. Minerva Chir 68(1): 1-9, 2013.

3 Rouanet P, Mourregot A, Azar CC, Carrere S, Gutowski M, Quenet F, Saint-Aubert B and Colombo PE: Transanal endoscopic proctectomy: An innovative procedure for difficult resection of rectal tumors in men with narrow pelvis. Dis Colon Rectum 56(4): 408-415, 2013.

4 Kumar AS, Coralic J, Kelleher DC, Sidani S, Kolli K and Smith LE: Complications of transanal endoscopic microsurgery are rare and minor: A single institution's analysis and comparison to existing data. Dis Colon Rectum 56(3): 295-300, 2013.

5 Duek SD, Kluger Y, Grunner S, Weinbroum AA and Khoury W: Transanal endoscopic microsurgery for the resection of submucosal and retrorectal tumors. Surg Laparosc Endosc Percutan Tech 23(1): 66-68, 2013.

6 Albert MR, Atallah SB, deBeche-Adams TC, Izfar S and Larach SW: Transanal minimally invasive surgery (tamis) for local excision of benign neoplasms and early-stage rectal cancer: Efficacy and outcomes in the first 50 patients. Dis Colon Rectum 56(3): 301-307, 2013.

7 Leonard D, Remue C and Kartheuser A: The transanal endoscopic microsurgery procedure: Standards and extended indications. Dig Dis 30(Suppl 2): 85-90, 2012.

8 Morino M, Arezzo A and Allaix ME: Transanal endoscopic microsurgery. Tech Coloproctol 17(Suppl 1): S55-61, 2013.

9 Amann M, Modabber A, Burghardt J, Stratz C, Falch C, Buess GF and Kirschniak A: Transanal endoscopic microsurgery in treatment of rectal adenomas and $\mathrm{t} 1$ low-risk carcinomas. World J Surg Oncol 10: 255, 2012.

10 Chen YY, Liu ZH, Zhu K, Shi PD and Yin L: Transanal endoscopic microsurgery versus laparoscopic lower anterior resection for the treatment of t1-2 rectal cancers. Hepatogastroenterology 60(124): 727-732, 2013.

11 Tajika M, Niwa Y, Bhatia V, Kondo S, Tanaka T, Mizuno N, Hara K, Hijioka S, Imaoka H, Ogura T, Haba S and Yamao K: Comparison of endoscopic submucosal dissection and endoscopic mucosal resection for large colorectal tumors. Eur J Gastroenterol Hepatol 23(11): 1042-1049, 2011.

12 Puia IC, Ionescu D, Cristea PG, Bala O, Graur F, Molnar G, Puia VR, Andreescu A and Iancu C: Transanal endoscopic microsurgery - our initial experience. Chirurgia (Bucur) 107(3): 332-336, 2012.

13 Han Y, He YG, Lin MB, Zhang YJ, Lu Y, Jin X and Li JW: Local resection for rectal tumors: Comparative study of transanal endoscopic microsurgery $v s$. Conventional transanal excision the experience in china. Hepatogastroenterology 59(120): 24902493, 2012.

14 Soreide K, Berg M, Skudal BS and Nedreboe BS: Advances in the understanding and treatment of colorectal cancer. Discov Med 12(66): 393-404, 2011.

15 Lin GL, Qiu HZ, Xiao Y, Wu B and Meng WC: Transanal endoscopic microsurgery for rectal intraepithelial neoplasia and early rectal carcinoma. Zhonghua Wei Chang Wai Ke Za Zhi 11(1): 39-43, 2008.

16 Jotautas V, Strupas K, Poskus E and Seinin D: Treatment of rectal tumors with transanal endoscopic microsurgery. Medicina (Kaunas) 41(6): 470-476, 2005. 
17 Papagrigoriadis S: Transanal endoscopic micro-surgery (tems) for the management of large or sessile rectal adenomas: A review of the technique and indications. Int Semin Surg Oncol 3: 13,2006

18 Levic K, Bulut O, Hesselfeldt P and Bulow S: The outcome of rectal cancer after early salvage surgery following transanal endoscopic microsurgery seems promising. Dan Med J 59(9): A4507, 2012.

19 Gawlick U, Lu KC, Douthit MA, Diggs BS, Schuff KG, Herzig DO and Tsikitis VL: Stage iii \& iv colon and rectal cancers share a similar genetic profile: A review of the oregon colorectal cancer registry. Am J Surg 205(5): 608-612; discussion 612, 2013.

20 Kohonen-Corish MR, Tseung J, Chan C, Currey N, Dent OF, Clarke S, Bokey L and Chapuis PH: Kras mutations and cdkn2a promoter methylation show an interactive adverse effect on survival and predict recurrence of rectal cancer. Int J Cancer 134(12): 2820-2828, 2014

21 Marone P, de Bellis M, D’Angelo V, Delrio P, Passananti V, Di Girolamo E, Rossi GB, Rega D, Tracey MC and Tempesta AM: Role of endoscopic ultrasonography in the loco-regional staging of patients with rectal cancer. World J Gastrointest Endosc 7(7): 688-701, 2015.

22 Gall TM, Markar SR, Jackson D, Haji A and Faiz O: Mini-probe ultrasonography for the staging of colon cancer: A systematic review and meta-analysis. Colorectal Dis 16(1): O1-8, 2014.

23 An C, Huh H, Han KH, Kim MJ, Kim NK, Kim H and Lim JS: Use of preoperative mri to select candidates for local excision of mri-staged $\mathrm{t} 1$ and $\mathrm{t} 2$ rectal cancer: Can mri select patients with n0 tumors? Dis Colon Rectum 58(10): 923-930, 2015.

24 Tarulli E, Thipphavong S and Jhaveri K: A structured approach to reporting rectal cancer with magnetic resonance imaging. Abdom Imaging 40(8): 3002-3011, 2015.

25 Church D, Midgley R and Kerr D: Biomarkers in early-stage colorectal cancer: Ready for prime time? Dig Dis 30(Suppl 2): 27-33, 2012.

26 Kalady MF, Dejulius KL, Sanchez JA, Jarrar A, Liu X, Manilich E, Skacel M and Church JM: Braf mutations in colorectal cancer are associated with distinct clinical characteristics and worse prognosis. Dis Colon Rectum 55(2): 128-133, 2012.

27 Petrelli F, Borgonovo K, Cabiddu M, Ghilardi M and Barni S: Cetuximab and panitumumab in kras wild-type colorectal cancer: A meta-analysis. Int J Colorectal Dis 26(7): 823-833, 2011.

28 Di Bartolomeo M, Pietrantonio F, Perrone F, Dotti KF, Lampis A, Bertan C, Beretta E, Rimassa L, Carbone C, Biondani P, Passalacqua R, Pilotti S, Bajetta E and Italian Trials in Medical Oncology G: Lack of kras, nras, braf and tp53 mutations improves outcome of elderly metastatic colorectal cancer patients treated with cetuximab, oxaliplatin and uft. Target Oncol 9(2): 155-162, 2014.

29 Corso G, Pascale V, Flauti G, Ferrara F, Marrelli D and Roviello F: Oncogenic mutations and microsatellite instability phenotype predict specific anatomical subsite in colorectal cancer patients Eur J Hum Genet 21(12): 1383-1388, 2013.

30 Corcoran RB, Ebi H, Turke AB, Coffee EM, Nishino M, Cogdill AP, Brown RD, Della Pelle P, Dias-Santagata D, Hung KE, Flaherty KT, Piris A, Wargo JA, Settleman J, Mino-Kenudson $\mathrm{M}$ and Engelman JA: Egfr-mediated re-activation of mapk signaling contributes to insensitivity of braf mutant colorectal cancers to raf inhibition with vemurafenib. Cancer Discov 2(3): 227-235, 2012.
31 Saridaki Z, Tzardi M, Papadaki C, Sfakianaki M, Pega F, Kalikaki A, Tsakalaki E, Trypaki M, Messaritakis I, Stathopoulos E, Mavroudis D, Georgoulias V and Souglakos J: Impact of kras, braf, pik3ca mutations, pten, areg, ereg expression and skin rash in $>/=2$ line cetuximab-based therapy of colorectal cancer patients. PLoS One 6(1): e15980, 2011.

32 Wang Q, Hu WG, Song QB and Wei J: Braf v600e mutation as a predictive factor of anti-egfr monoclonal antibodies therapeutic effects in metastatic colorectal cancer: A meta-analysis. Chin Med Sci J 29(4): 197-203, 2014.

33 Lee JK and Chan AT: Molecular prognostic and predictive markers in colorectal cancer: Current status. Curr Colorectal Cancer Rep 7(2): 136-144, 2011.

34 Phipps AI, Buchanan DD, Makar KW, Burnett-Hartman AN, Coghill AE, Passarelli MN, Baron JA, Ahnen DJ, Win AK, Potter JD and Newcomb PA: Braf mutation status and survival after colorectal cancer diagnosis according to patient and tumor characteristics. Cancer Epidemiol Biomarkers Prev 21(10): 1792-1798, 2012.

35 Rosty C, Young JP, Walsh MD, Clendenning M, Walters RJ, Pearson S, Pavluk E, Nagler B, Pakenas D, Jass JR, Jenkins MA, Win AK, Southey MC, Parry S, Hopper JL, Giles GG, Williamson E, English DR and Buchanan DD: Colorectal carcinomas with kras mutation are associated with distinctive morphological and molecular features. Mod Pathol 26(6): 825-834, 2013.

36 Lochhead P, Kuchiba A, Imamura Y, Liao X, Yamauchi M, Nishihara R, Qian ZR, Morikawa T, Shen J, Meyerhardt JA, Fuchs CS and Ogino S: Microsatellite instability and braf mutation testing in colorectal cancer prognostication. J Natl Cancer Inst 105(15): 1151-1156, 2013.

37 Yuan ZX, Wang XY, Qin QY, Chen DF, Zhong QH, Wang L and Wang JP: The prognostic role of braf mutation in metastatic colorectal cancer receiving anti-egfr monoclonal antibodies: A meta-analysis. PLoS One 8(6): e65995, 2013.

38 Roth AD, Tejpar S, Delorenzi M, Yan P, Fiocca R, Klingbiel D, Dietrich D, Biesmans B, Bodoky G, Barone C, Aranda E, Nordlinger B, Cisar L, Labianca R, Cunningham D, Van Cutsem E and Bosman F: Prognostic role of kras and braf in stage ii and iii resected colon cancer: Results of the translational study on the petacc-3, eortc 40993, sakk 60-00 trial. J Clin Oncol 28(3): 466-474, 2010.

39 Chen D, Huang JF, Liu K, Zhang LQ, Yang Z, Chuai ZR, Wang YX, Shi DC, Huang Q and Fu WL: Brafv600e mutation and its association with clinicopathological features of colorectal cancer: A systematic review and meta-analysis. PLoS One 9(3): e90607, 2014.

40 Mao C, Liao RY, Qiu LX, Wang XW, Ding H and Chen Q: Braf v600e mutation and resistance to anti-egfr monoclonal antibodies in patients with metastatic colorectal cancer: A metaanalysis. Mol Biol Rep 38(4): 2219-2223, 2011.

41 Rizzo S, Bronte G, Fanale D, Corsini L, Silvestris N, Santini D, Gulotta G, Bazan V, Gebbia N, Fulfaro F and Russo A: Prognostic vs predictive molecular biomarkers in colorectal cancer: Is kras and braf wild type status required for anti-egfr therapy? Cancer Treat Rev 36(Suppl 3): S56-61, 2010.

42 Domingo E, Ramamoorthy R, Oukrif D, Rosmarin D, Presz M, Wang H, Pulker H, Lockstone H, Hveem T, Cranston T, Danielsen H, Novelli M, Davidson B, Xu ZZ, Molloy P, Johnstone E, Holmes C, Midgley R, Kerr D, Sieber O and Tomlinson I: Use of multivariate analysis to suggest a new molecular classification of colorectal cancer. J Pathol 229(3): 441-448, 2013. 
43 Ogino S, Nosho K, Kirkner GJ, Kawasaki T, Meyerhardt JA, Loda M, Giovannucci EL and Fuchs CS: Cpg island methylator phenotype, microsatellite instability, braf mutation and clinical outcome in colon cancer. Gut 58(1): 90-96, 2009.

44 Inno A, Fanetti G, Di Bartolomeo M, Gori S, Maggi C, Cirillo M, Iacovelli R, Nichetti F, Martinetti A, de Braud F, Bossi I and Pietrantonio F: Role of mgmt as biomarker in colorectal cancer. World J Clin Cases 2(12): 835-839, 2014.

45 Chen YZ, Liu D, Zhao YX, Wang HT, Gao Y and Chen Y: Relationships between p16 gene promoter methylation and clinicopathologic features of colorectal cancer: A meta-analysis of 27 cohort studies. DNA Cell Biol 33(10): 729-738, 2014.

46 Hibi K, Mizukami H, Saito M, Kigawa G and Nemoto H: P16 methylation is frequently detected in the serum of metastatic colorectal cancer patients. Hepatogastroenterology 61(130): 354356, 2014.

47 Kuan JC, Wu CC, Sun CA, Chu CM, Lin FG, Hsu CH, Kan PC, Lin SC, Yang T and Chou YC: DNA methylation combinations in adjacent normal colon tissue predict cancer recurrence: Evidence from a clinical cohort study. PLoS One 10(3): e0123396, 2015.
48 Serra RW, Fang M, Park SM, Hutchinson L and Green MR: A kras-directed transcriptional silencing pathway that mediates the cpg island methylator phenotype. Elife 3: e02313, 2014.

49 Bandapalli OR, Dihlmann S, Helwa R, Macher-Goeppinger S, Weitz J, Schirmacher P and Brand K: Transcriptional activation of the beta-catenin gene at the invasion front of colorectal liver metastases. J Pathol 218(3): 370-379, 2009.

50 Pacheco-Pinedo EC and Morrisey EE: Wnt and kras signalingdark siblings in lung cancer. Oncotarget 2(7): 569-574, 2011. 